\title{
Refolding through a linear transition state enables fast temperature adaptation of a translational riboswitch
}

Boris Fürtig ${ }^{*},{ }^{[a]}$ Eva Marie Oberhauser, ${ }^{[b]}$ Heidi Zetzsche, ${ }^{[a]}$ Dean-Paulos Klötzner, ${ }^{[b]}$ Alexander Heckel, ${ }^{[b]}$ and Harald Schwalbe* ${ }^{[a]}$.

[a] Johann Wolfgang Goethe University, Institute of Organic Chemistry and Chemical Biology, Center for Biomolecular Magnetic Resonance (BMRZ), Max von Laue Str. 7, 60438 Frankfurt/Main

(Germany), [b] Institute of Organic Chemistry and Chemical Biology, Max von Laue Str. 7, 60438

Frankfurt/Main (Germany); ; fuertig@nmr.uni-frankfurt.de; *schwalbe@nmr.uni-frankfurt.de
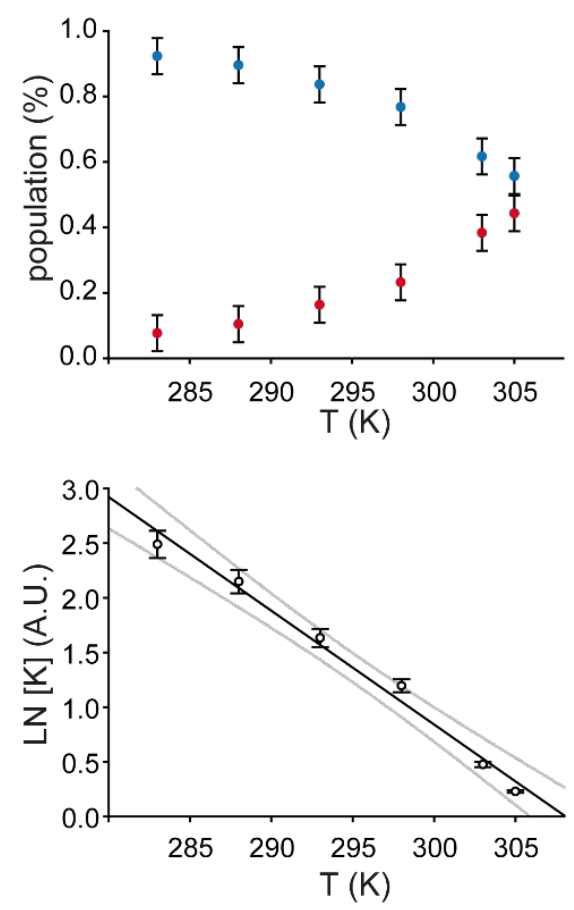

Figure S1: Van't Hoff Analysis of the conformational equilibrium between apoA and apoB. 

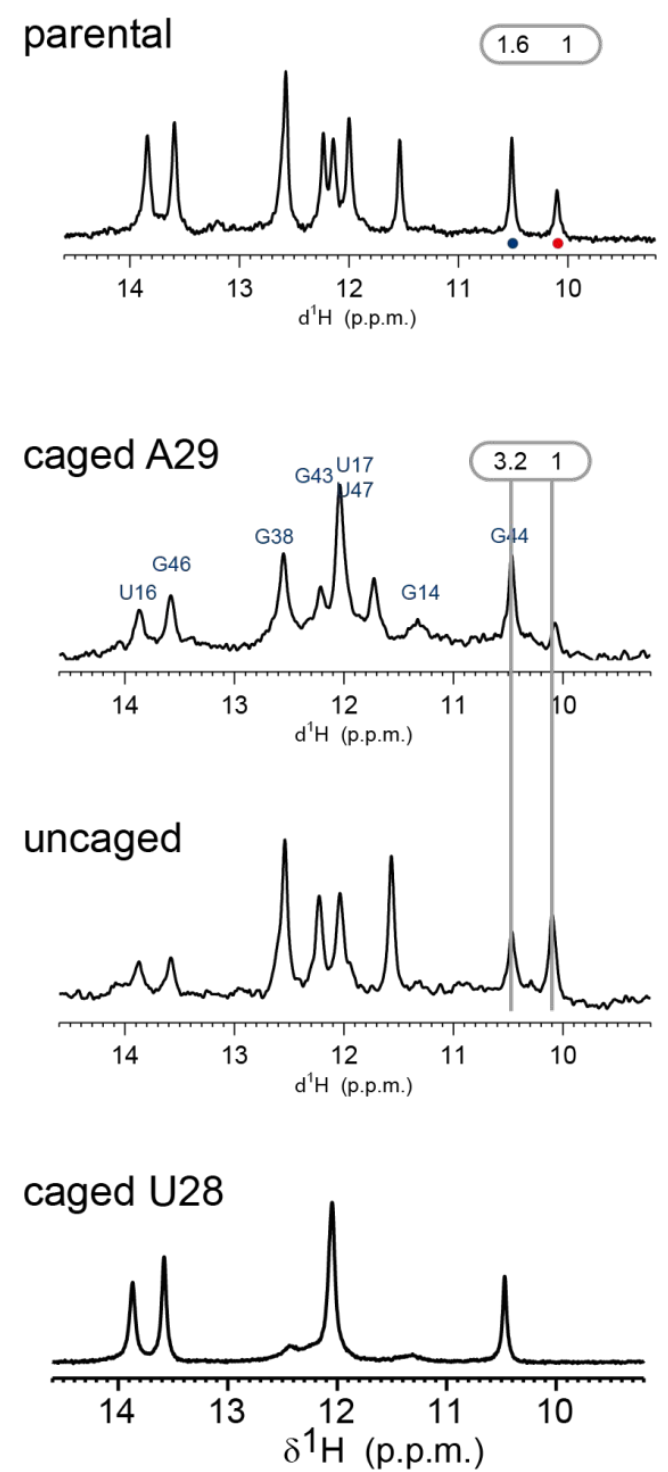

Figure S2: Comparison of imino-proton region of $1 \mathrm{D}^{1} \mathrm{H}$ spectra $(800 \mathrm{MHz}$, jump return echo for water suppression, 512 scans) of unmodified $35 \mathrm{nt}$ long TRM (parental RNA) with the same sequence that contains a NPE-caged A at position 29; although after deprotection (1s laser pulse at 4.5W, 355nm) equilibrium could be restored, incorporation does not yield exclusive stabilization of a single conformation as compared to the TRM caged at position U28 that leads to a exclusive stabilization of conformation apoB.

Introduction of a NPE-caged adenosine at position A29 was initially assumed to destabilize apoAconformation and consequently shift the equilibrium to an exclusive population of conformation apoB. As evident from the above described experiments, however, the nucleotide at position 29 is not involved in a stable base pair with U41. Consequently, the destabilization effect of the introduced photo-caged adenosine at this position was smaller as the energy difference between the two states and did not result in the preferential population of the apoB conformational state 


\section{Experimental Procedures}

\section{NMR spectroscopy:}

All NMR spectroscopic experiments were carried out on a BrukerAVII $800 \mathrm{MHz}$ spectrometer, equipped with a 5-mm TXI- HCN cryogenic probe with z-axis gradients; RNA assignment experiments ${ }^{1}$, laser assisted in situ deprotection experiments ${ }^{2}$ and exchange experiments ${ }^{3,4}$ were carried out as described in the respective literature.

Biophysical Analysis:

Van't Hoff Analysis

For the determination of the equilibrium constant $\mathrm{K}$ the ratio between the populations of conformation apo $A$ and conformation apoB as derived from the relative intensities of the respective imino-proton signals was build. The temperature dependent data were fitted against $\Delta G=-R^{*} T^{*} L N[K]$.

\section{ZZ-Exchange}

The ZZ-Exchange curves were analyzed according to the formulae derived in Farrow et al. 1994[4]

\section{Arrhenius/Eyring Analysis}

The Gibb energies of activation were extracted from the temperature dependence of exchange rates determined by the ZZ-exchange experiment. It is derived from fitting the Eyring equation $k e x=\frac{k_{b} T}{h} e^{-\frac{\Delta G}{R T}}$ to the experimental data.

\section{Biochemical Synthesis of isotope labelled RNA:}

A uniformly ${ }^{13} \mathrm{C},{ }^{15} \mathrm{~N}$-labelled bistable $35 \mathrm{mer}$ RNA derived from the adenine-dependent riboswitch of Vibrio vulnificus (5'-pppGCUUCAUAUAAUCCUAAUGAUAUGGUUUGGGAGUU-3') was prepared by in vitro transcription from a Smal linearized DNA template (modified pUC57-plasmid). 100 $\mathrm{mM}$ Tris-glutamic acid (pH 8.1), $2 \mathrm{mM}$ spermidine, $45 \mathrm{mM} \mathrm{Mg}(\mathrm{OAc})_{2}, 4 \mathrm{mM}{ }^{13} \mathrm{C},{ }^{15} \mathrm{~N}$-labelled rNTPs and $300 \mathrm{ng} / \mu \mathrm{L}$ DNA template were incubated for $30 \mathrm{~min}$ at $37^{\circ} \mathrm{C}$ before $20 \mathrm{mM}$ DTT and $70 \mu \mathrm{g} / \mathrm{mL}$ T7polymerase were added. Incubation was continued for 4 hours with addition of 1 unit/mL pyrophosphatase after 2 hours. The RNA product was purified by anion exchange chromatography using a DEAE sepharose resin with an elution gradient of 0.6 to $3 \mathrm{M} \mathrm{NaOAc}$ followed by a reversed phase HPLC. After $\mathrm{LiClO}_{4}$ precipitation and desalting the RNA was folded by heating up to $90^{\circ} \mathrm{C}$ and then rapidly diluted to $4^{\circ} \mathrm{C}$. The final sample concentration was $200 \mu \mathrm{M}$ RNA in $25 \mathrm{mM}$ potassium phosphate, $50 \mathrm{mM} \mathrm{KCl}$ at $\mathrm{pH} 6.5$ in $90 \% \mathrm{H}_{2} \mathrm{O}$ and $10 \% \mathrm{D}_{2} \mathrm{O}$.

\section{RNA Solid-phase synthesis:}

The NPE-photocaged phosphoramidites were synthesized according to the literature. ${ }^{5}$ The solid-phase syntheses of the RNAs were performed either by Axolabs GmbH (Kulmbach, Germany) or on an Expedite synthesizer from Perseptive Biosystems using 2'-TBDMS RNA SynBaseTM 1000 A CPG columns and 2'-TBDMS RNA phosphoramidites from SAFC Proligo. The oligonucleotides were synthesized in DMTr-off mode using modified synthesis protocols with 12 minutes coupling time for standard 2'-TBDMS amidites and 15 minutes coupling time for caged amidites. ETT was used as activator in a $0.35 \mathrm{M}$ concentration. Phosphoramidites were used at $0.1 \mathrm{M}$ concentration.

When U-NPE was incorporated G-iPrPac-phosphoramidite or fast deprotection amidites, with tertphenoxyacetyl (tac) as exocyclic protection group were used. Fast deprotection Cap A solution, containing $5 \%$ tert-butylphenoxyacetyl acetic anhydride $\left(\mathrm{TAC}_{2} \mathrm{O}\right)$ in tetrahydrofuran, was used in place of Cap A solution to ensure that the displacement of tert-butylphenoxyacetyl (tac) on guanine bases of the TAC-protected RNA phosphoramidites did not occur. 
For RNA that contained an NPE-adenosine, deprotection was performed as follows: The CPG was treated with a mixture of $\mathrm{NH}_{3} / \mathrm{EtOH} 3: 1$ at $40^{\circ} \mathrm{C}$ for $24 \mathrm{~h}$, the supernatant was collected, the $\mathrm{CPG}$ washed with DEPC-treated water, vortexed, and the combined supernatants were dried in a vacuum concentrator. The dried RNA was dissolved in a mixture of NMP/TEA/TEA.3HF (300 $\mu \mathrm{L} \mathrm{NMP/150 \mu l}$ TEA/200 $\mu \mathrm{L}$ TEA.3HF) and incubated for 90 minutes at $60{ }^{\circ} \mathrm{C} .1 .4 \mathrm{~mL} n$-Butanol were added and precipitation was performed overnight at $-20{ }^{\circ} \mathrm{C}$ or for a minimum of $1 \mathrm{~h}$ at $-80{ }^{\circ} \mathrm{C}$. Centrifugation was performed for 30 minutes at $0{ }^{\circ} \mathrm{C}$ and $12500 \mathrm{rpm}$, the supernatant was discarded, and the RNA was dissolved in DEPC-treated water for further purification via HPLC.

For RNA that incorporated an NPE-uridine and G-iPrPac-phosphoramidite, deprotection was performed as follows: The CPG was treated with a mixture of $\mathrm{NH}_{3} / \mathrm{EtOH} 3: 1$ at $25^{\circ} \mathrm{C}$ for $4 \mathrm{~h}$, the supernatant was collected, the CPG was washed with DEPC-treated water, vortexed and the combined supernatants were dried in a vacuum concentrator. The residue was dissolved in a mixture of NMP/TEA/TEA $3 \mathrm{HF}$ $(300 \mu \mathrm{L} \mathrm{NMP} / 150 \mu \mathrm{L} \mathrm{TEA} / 200 \mu \mathrm{L}$ TEA$\cdot 3 \mathrm{HF})$ and incubated for $12 \mathrm{~h}$ at $25^{\circ} \mathrm{C} .1 .4 \mathrm{~mL} n$-Butanol were added and precipitation was performed over night at $-20{ }^{\circ} \mathrm{C}$ or for a minimum of $1 \mathrm{~h}$ at $-80{ }^{\circ} \mathrm{C}$. Centrifugation was performed for 30 minutes at $0{ }^{\circ} \mathrm{C}$ and $12500 \mathrm{rpm}$, the supernatant discarded and the RNA was dissolved in DEPC-treated water for further purification via HPLC.

For RNA that incorporates an NPE-uridine and tac-protection groups, deprotection was performed as follows: The CPG was treated with a mixture of $\mathrm{NH}_{3} / \mathrm{EtOH} \mathrm{3:1} \mathrm{at} 25{ }^{\circ} \mathrm{C}$ for $2.5 \mathrm{~h}$, the supernatant was kept, the CPG washed again with $\mathrm{NH}_{3} / \mathrm{EtOH} 3: 1$, vortexed and the combined supernatants were dried in a vacuum concentrator. The residue was dissolved in a mixture of AMA/DMSO $(0.5 \mathrm{~mL} / 1.5 \mathrm{~mL})$ and stored for 10 minutes at $-20^{\circ} \mathrm{C}$. Then $0.75 \mathrm{~mL}$ TEA $3 \mathrm{HF}$ were added and the mixture was incubated at $45^{\circ} \mathrm{C}$ for $1 \mathrm{~h}$. The $\mathrm{pH}$ was adjusted to 5 by adding $0.1 \mathrm{M}$ TEAA $(\mathrm{pH} 7)$.

\section{HPLC-Purification}

Separation of the RNAs by length was performed via ion exchange-HPLC:

Column: $\quad$ DNA-Pac PA-100, Dionex, 9 × $250 \mathrm{~mm}$

Temperature: $80^{\circ} \mathrm{C}$

Buffer A: $\quad$ DEPC-water

Buffer B: $\quad 1 \mathrm{M} \mathrm{LiCl}$ in DEPC-water

Flow: $\quad 5 \mathrm{~mL} / \mathrm{min}$

Gradient: $\quad 0 \%$ Buffer $B \rightarrow 80 \%$ Buffer B in 50 minutes

Separation of the caged and uncaged products were performed via RP-HPLC:

Column: $\quad$ Nucleosil C12, Phenomenex, $9 \times 250 \mathrm{~mm}$

Buffer A: $\quad 0.1 \mathrm{M}$ TEAA-Puffer, $\mathrm{pH} 7$, in DEPC-water

Buffer B: acetonitrile

Flow: $\quad 6 \mathrm{~mL} / \mathrm{min}$

Gradient: $\quad 0 \%$ buffer $B \rightarrow 43 \%$ buffer B in 35 minutes

Purification of the tac-protected RNAs were performed on Äkta Purifier from GE Healthcare

Column: $\quad$ Waters XBridge BEH C18 ODB Prep Column, $130 \AA, 10$ x $50 \mathrm{~mm}$

Temperature: $60^{\circ} \mathrm{C}$

Buffer A: $\quad 0.1 \mathrm{M}$ TEAA

Buffer B: $\quad 0.1 \mathrm{M}$ TEAA in $95 \% \mathrm{MeCN}$

Flow: $\quad 4 \mathrm{~mL} / \mathrm{min}$

Gradient: $\quad 2 \% B \rightarrow 20 \% B$ in 35 minutes

Table S 1: Sequences of the synthesized oligonucleotides

\begin{tabular}{|l|l|}
\hline & Sequence \\
\hline 1 & 5 -GCUUCAUAUAAUCCUANPEAUGAUAUGGUUUGGGAGUU-3‘ \\
\hline 2 & $5^{\prime}$-GCUNPEUCAUAUAAUCCUAAUGAUAUGGUUUGGGAGUU-3‘ \\
\hline
\end{tabular}




\section{5'-GCUUCAUAUAAUCCUNPEAAUGAUAUGGUUUGGGAGUU-3“}

Table S 2: ESI-MS data of synthesized oligonucleotides

\begin{tabular}{|l|l|l|}
\hline Sequence & Mass calc. [Da] & Mass found [Da] \\
\hline 1 & 11312 & 11317 \\
\hline 2 & 11312 & $11358\left[\mathrm{M}+2 \mathrm{Na}^{+}\right]$ \\
\hline 3 & 11312 & 11319 \\
\hline
\end{tabular}




\section{References}

[1] Fürtig, B., Richter, C., Wöhnert, J. \& Schwalbe, H. NMR spectroscopy of RNA. Chembiochem 4, 936-62 (2003).

[2] Wenter, P., Fürtig, B., Hainard, A., Schwalbe, H. \& Pitsch, S. Kinetics of photoinduced RNA refolding by real-time NMR spectroscopy. Angew. Chem. Int. Ed. Engl. 44, 2600-3 (2005).

[3] Farrow, N. a, Zhang, O., Forman-Kay, J. D. \& Kay, L. E. A heteronuclear correlation experiment for simultaneous determination of $15 \mathrm{~N}$ longitudinal decay and chemical exchange rates of systems in slow equilibrium. J. Biomol. NMR 4, 727-34 (1994).

[4] Rinnenthal, J., Klinkert, B., Narberhaus, F. \& Schwalbe, H. Direct observation of the temperature induced melting process of the Salmonella fourU RNA thermometer at base-pair resolution. Nucleic Acids Res. 38, 3834-47 (2010).

[5] Höbartner, C. \& Silvermann, S.K. Modulation of RNA tertiary folding by incorporation of caged nucleotides. Angew. Chem. Int. Ed. 44, 7305-09 (2006). 